\title{
Geologic Map of the Fish Creek Reservoir 7.5' Quadrangle, Blaine County, Idaho
}

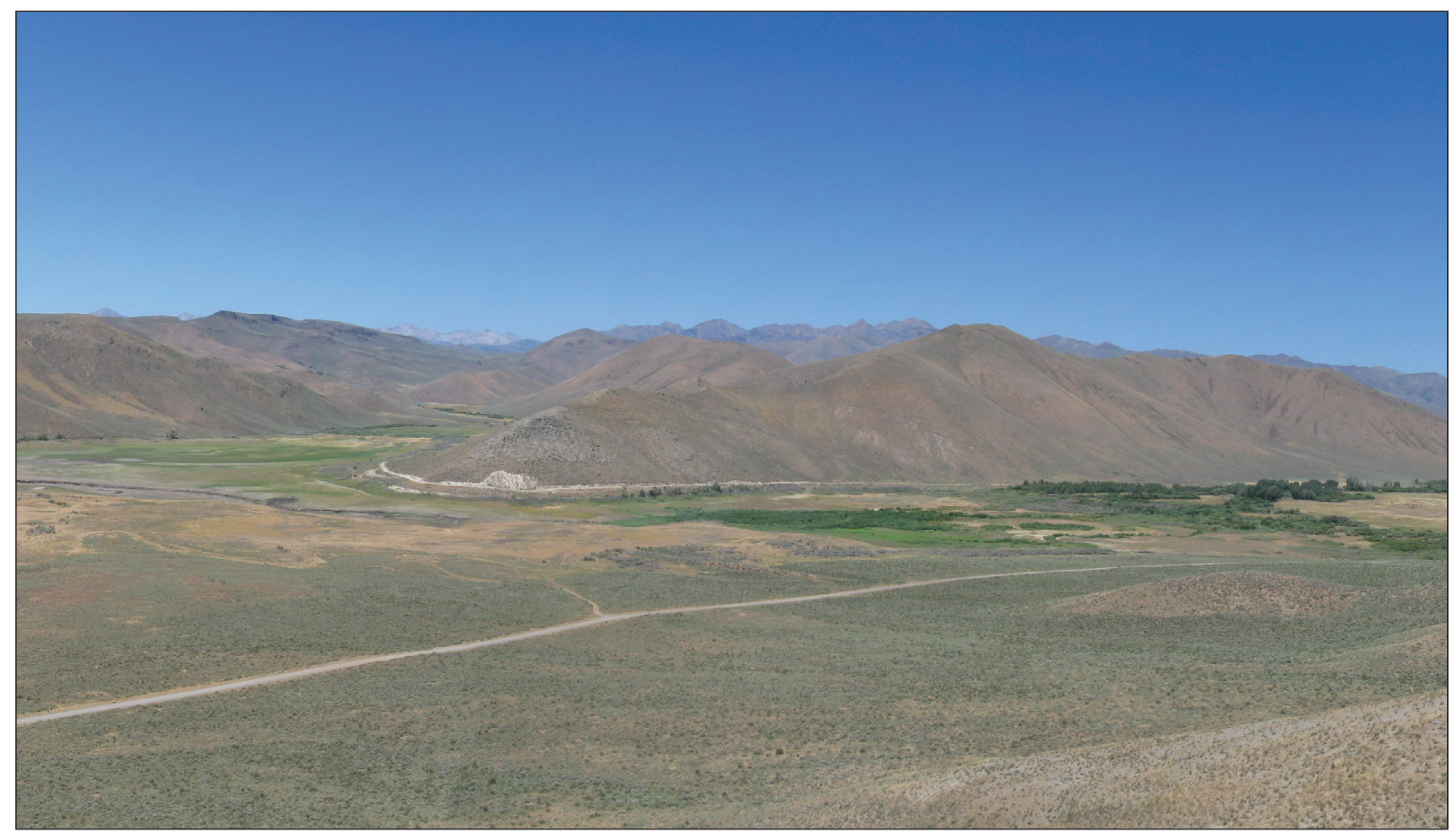

Scientific Investigations Map 3191 


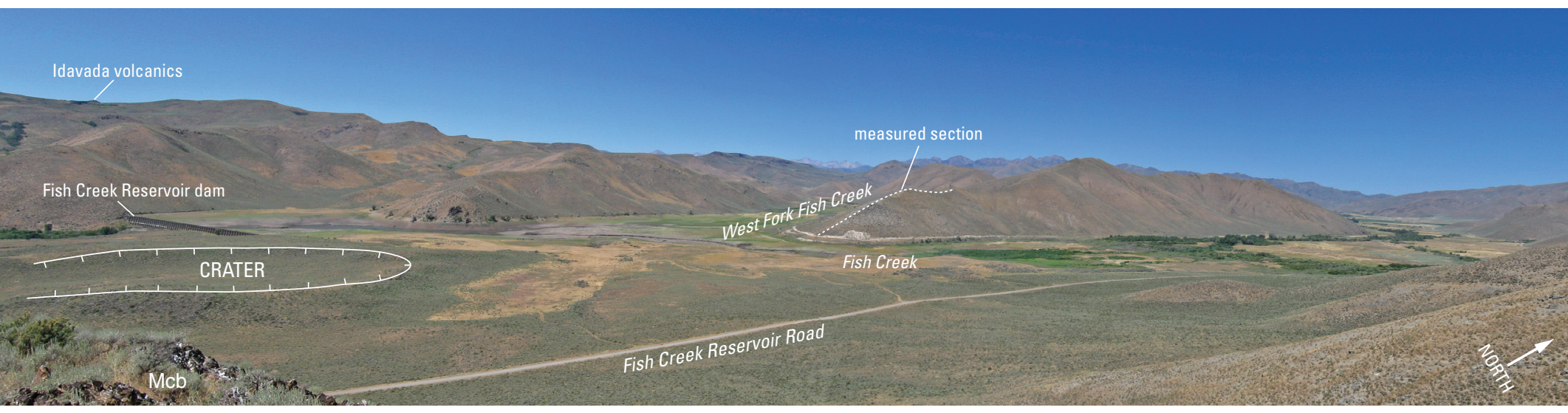

FRONT COVER: View looking west from low hill on east side of Fish Creek (see red star on geologic map), showing Fish Creek dam and reservoir, nearly dry; location of measured section (white dashed line on ridge) of lower Paleozoic carbonate rocks (Skipp and Sandberg, 1975); rim of crater, source for basalt flow of Snake River Group, and the junction of Fish Creek and West Fork of Fish Creek. Flat-lying distant caprock on Wood River Formation is rhyolitic ignimbrite of Miocene Idavada Volcanics. Mcb = Copper Basin Group 


\section{Geologic Map of the Fish Creek Reservoir 7.5' Quadrangle, Blaine County, Idaho}

By Betty Skipp and Theodore R. Brandt

Scientific Investigations Map 3191 


\title{
U.S. Department of the Interior \\ KEN SALAZAR, Secretary \\ U.S. Geological Survey \\ Marcia K. McNutt, Director
}

\author{
U.S. Geological Survey, Reston, Virginia: 2012
}

For more information on the USGS - the Federal source for science about the Earth, its natural and living resources, natural hazards, and the environment, visit http://www.usgs.gov or call 1-888-ASK-USGS.

For an overview of USGS information products, including maps, imagery, and publications, visit http://www.usgs.gov/pubprod

To order this and other USGS information products, visit http://store.usgs.gov

Any use of trade, product, or firm names is for descriptive purposes only and does not imply endorsement by the U.S. Government.

Although this report is in the public domain, permission must be secured from the individual copyright owners to reproduce any copyrighted materials contained within this report.

Suggested citation:

Skipp, Betty, and Brandt, T.R., 2012, Geologic map of the Fish Creek Reservoir 7.5' quadrangle, Blaine County, Idaho: U.S. Geological Survey Scientific Investigations Map 3191, 1 sheet, scale 1:24,000, pamphlet, 15 p. 


\section{Contents}

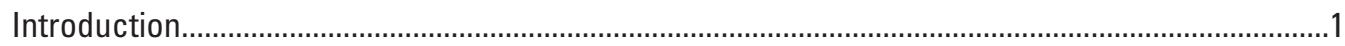

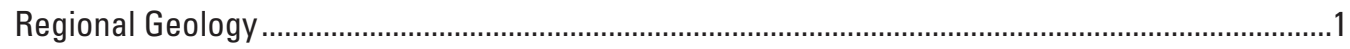

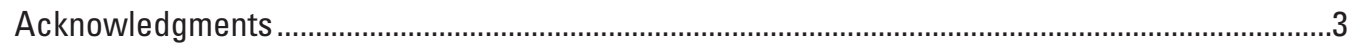

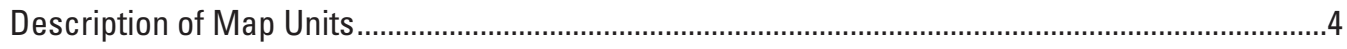

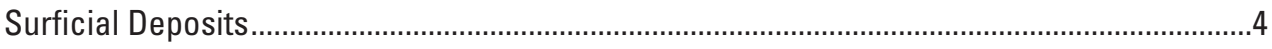

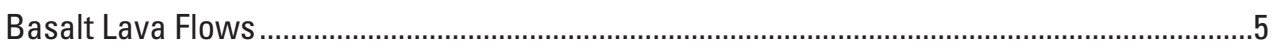

Craters of the Moon Volcanic Field .............................................................................. 5

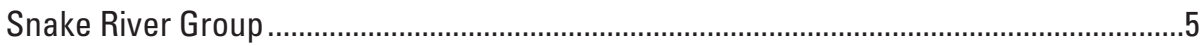

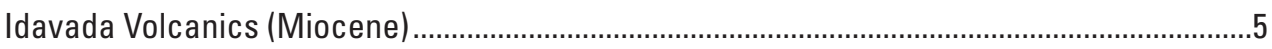

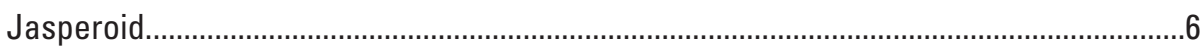

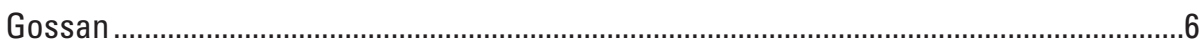

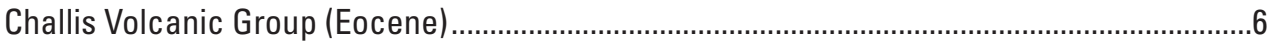

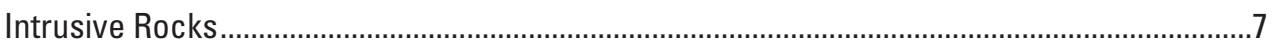

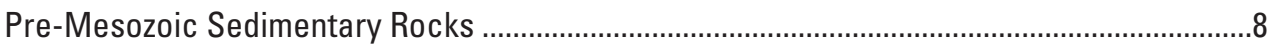

Hanging Wall of Pioneer Thrust Fault............................................................................ 8

Footwall of Antler-age Thrust Fault ...............................................................................

Hanging Wall of Antler-age Thrust Fault............................................................................

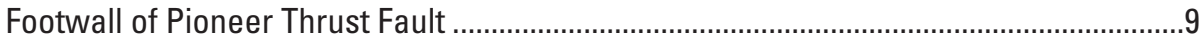

Copper Basin Group (Mississippian) ......................................................................

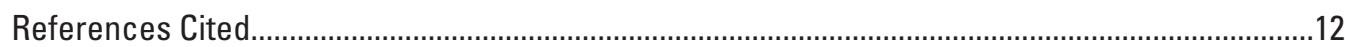

\section{Figure}

1. Diagrammatic map of south-central Idaho showing location of the Fish Creek Reservoir quadrangle in relation to geographic and geologic features .......................... 



\title{
Geologic Map of the Fish Creek Reservoir 7.5' Quadrangle, Blaine County, Idaho
}

\author{
By Betty Skipp and Theodore R. Brandt
}

\section{Introduction}

The Fish Creek Reservoir quadrangle in south-central Idaho lies on the north-central margin of the Cenozoic Snake River Plain at the southern end of the Pioneer Mountains (fig. 1). Rocks exposed in the quadrangle range in age from Paleozoic through Cenozoic. Mesozoic rocks are absent. Though Triassic and Jurassic sedimentary rocks may have been deposited in this area, they would have been removed by erosion following uplift and thrusting of the Late Cretaceous to early Tertiary Sevier orogeny (Skipp and others, 2009). Mesozoic igneous rocks, satellites of the Atlanta lobe of the Idaho batholith, may be present at depth (Rodgers and others, 1995).

\section{Regional Geology}

The region is underlain by Precambrian (Archean and Proterozoic) rocks shown to be present in the Pioneer Mountains core complex to the northwest (PMCC, fig. 1; Link and others, 2007; Link and others, 2010). Two facies of Paleozoic sedimentary rocks were deposited on this western margin of Paleozoic North America (Laurentia). The two faulted and folded Paleozoic sequences are in contact along the Pioneer thrust fault of probable Late Cretaceous age (Dover, 1983; Link and others, 1995; Kuntz and others, 2007; Skipp and others, 2009). Both north and immediately south of the Pioneer Mountain core complex, the westernmost Paleozoic sequence consists of Devonian black argillite and quartzite deep-water facies of the Milligen Formation overlain unconformably by Upper Paleozoic basinal carbonates of the Pennsylvanian and Permian Wood River Formation. This western sequence is thrust over Mississippian western-derived flysch of the Copper Basin Group (Mcb) that unconformably overlies lower Paleozoic carbonate rocks (Skipp and Sandberg, 1975; Link and others, 1995; Skipp and others, 2009). In the northern PMCC area, the older Devonian black shales overlain by the Wood River Formation are in thrust contact with the younger Mississippian Copper Basin Group along the Pioneer thrust fault (fig. 1). Between these northern exposures of the fault in the vicinity of the Pioneer Mountains core complex and the southern exposures in the Fish Creek
Reservoir quadrangle, the thrust fault is buried beneath Eocene volcanics of the Challis Volcanic Group (Skipp and others, 2009; fig. 1). Where the thrust fault crops out in the southern Fish Creek Reservoir area, younger carbonate rocks of the Pennsylvanian and Permian Wood River Formation directly overlie older flysch of the Mississippian Copper Basin Group.

Younger-over-older thrust relations are not typical for thrust faults formed during a single compressional event, even when normal movement in the opposite direction is a factor. In this area, however, the relations are interpreted to have resulted from complications resulting from two separate, but areally overlapping, periods of compression of different ages, in addition to later extensional movement. The first period of thrusting is interpreted to represent the Antler (latest Devonian to Early Mississippian) period of compression; the second, a Late Cretaceous to early Tertiary Sevier orogenic event. The period of Antler thrusting is interpreted to be represented by the Ordovician through Devonian rocks of differing western and eastern facies, exposed in two closely spaced windows eroded through overlying Tertiary volcanic rocks in the southern part of the Fish Creek Reservoir quadrangle.

Lower Paleozoic western facies rocks exposed in one structural window in the southwestern part of this quadrangle west of Fish Creek have been assigned to the Ordovician and Silurian Phi Kappa (SOp) and Trail Creek (St) Formations of Ordovician age and unnamed Devonian and Silurian calcareous sandstones as described by Dover (1981, 1983), and Link and others (1995) in the central Pioneer Mountains. Graptolites of Ordovician age that support these formation assignments were recovered locally from the Phi Kappa Formation (SOp) (Otto and Zieg, 2003; Kuntz and others, 2007; fossil localities F-2, F-3, and F-4 on map). These lower Paleozoic rocks are interpreted to be deformed along an older-over-younger thrust segment overlain unconformably by fossiliferous rocks of the Middle Pennsylvanian Hailey Member (Pwh), the lowest member of the basinal Pennsylvanian and Permian Wood River Formation. Cross sections $A-A^{\prime}$ and $B-B^{\prime}$ illustrate these structural interpretations. A different structural interpretation of this southwestern window was published by Otto and Zieg, (2003) who did not recognize the presence of the Wood River Formation, but who provided valuable detailed descriptions of the older rocks. The present interpretations supersede an earlier version of the structure of part of the area published by Skipp and Hall in 1975. 


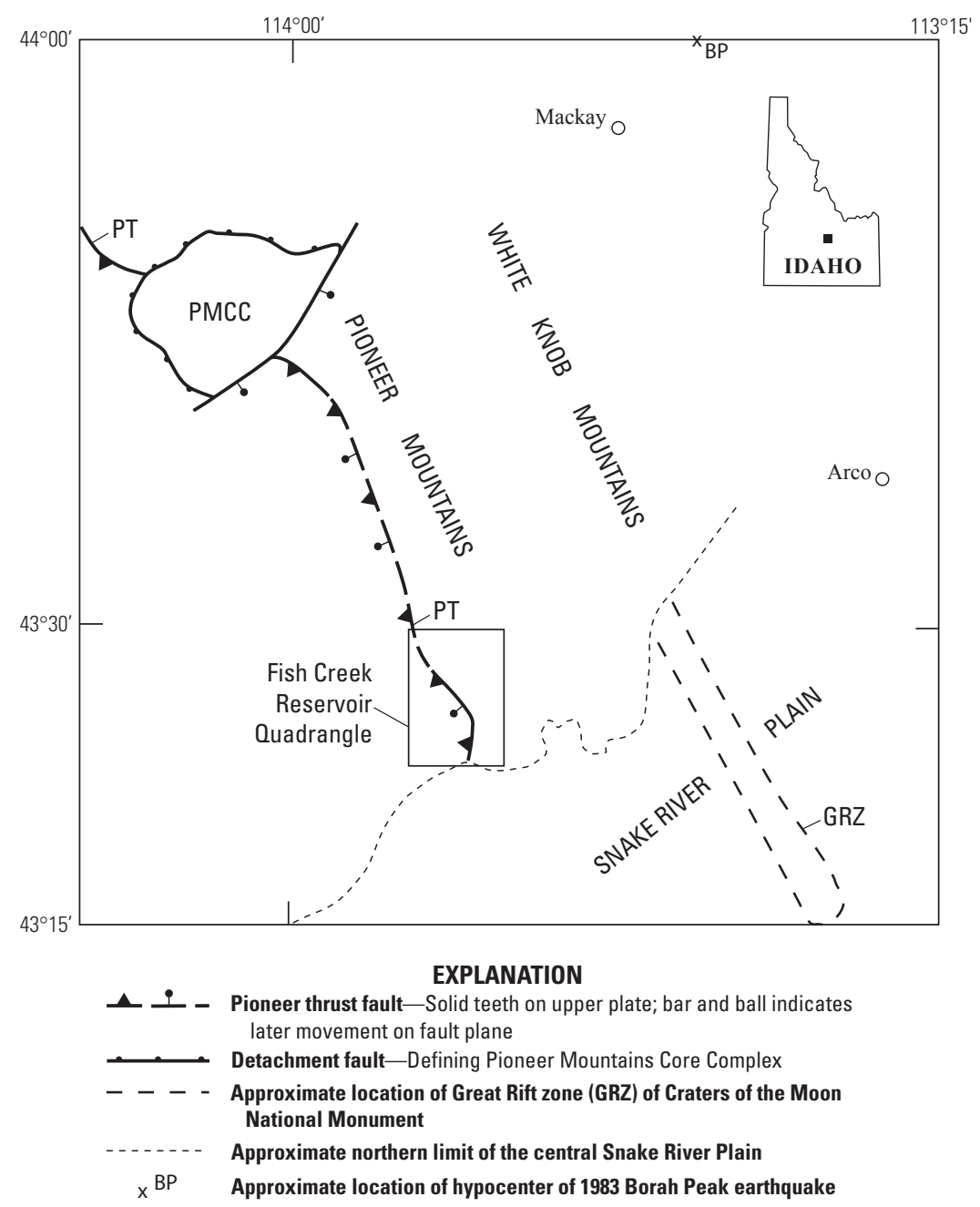

Figure 1. Diagrammatic map of south-central Idaho showing location of the Fish Creek Reservoir quadrangle in relation to geographic and geologic features referenced in text: Pioneer Mountains; White Knob Mountains; Pioneer Mountain Core Complex (PMCC); Pioneer thrust (PT); approximate northern limit of the central Snake River Plain; Great Rift zone (GRZ); approximate location of hypocenter of 1983 Borah Peak earthquake (BP); and local towns, Arco and Mackay. The entire region is located within the Intermountain seismic zone.

The western facies rocks of early Paleozoic age in this southwestern part of the quadrangle are exposed in a structural window formed by doming above a buried granodiorite intrusive of possibly Cretaceous (Rodgers and others, 1995), but more probably, Tertiary age, encountered at $200-\mathrm{ft}$ depth in a drill hole at the mouth of Long Canyon (Cominco American Resources Incorporated drill hole LC-3; Otto and Zieg, 2003). A late Tertiary (Miocene) age for the granodiorite is suggested by the doming and faulting of outcrops of the Miocene Idavada Volcanics that surround the Paleozoic and Eocene outcrops. This interpretation is illustrated in cross-section $A-A^{\prime}$.

Northeast of the Long Canyon structural window, on the east side of Fish Creek, just east of a Cenozoic basalt vent, the second structural window is present in an upraised block also interpreted here to be underlain by a late Tertiary(?) intrusive, though no deeper drill hole data are available for this area; other structural interpretations are possible. Here the upraised, fossiliferous lower Paleozoic carbonate geosynclinal and transitional carbonate rocks (Skipp and Sandberg, 1975) are duplicated by a thrust fault also presumed to be of Antler age. The faulted lower Paleozoic carbonates are overlain unconformably by Mississippian flysch of the Copper Basin Group (Mcb). The Mississippian flysch, in turn, is overlain locally by deformed Eocene and Miocene volcanic rocks (interpretive cross-sections $B-B^{\prime}$ and $C-C^{\prime}$ ).

Possible additional evidence of the presence of Antlerage thrusting in this part of Idaho has been reported by Link and others (2010) from the Pioneer Mountains core complex (fig. 1, PMCC), where new sensitive high-resolution ion microprobe (SHRIMP) ages obtained on contained zircons 
show that Archean gneiss structurally overlies Proterozoic sedimentary rocks in the central area of the core complex, whereas the oldest rocks involved in younger Sevier thrusting in the area surrounding the core complex are argillite and related facies of the Devonian Milligen Formation.

During Eocene time, deposits of the Challis Volcanic Group buried all exposed Paleozoic rocks. Thick conglomerates (TCC) found in places at the base of the mostly volcanic Eocene rock sequence are made up of rounded cobbles and boulders derived from the Copper Basin Group (Mcb). These deposits are remnants of an extensive stream system formed prior to the eruption of the volcanic rocks in this area (Paull, 1974). The conglomerates are unconformable beneath the overlying volcanic rocks and reflect the structural instability of the area before eruption of the first volcanic rocks about $52 \mathrm{Ma}$ (Beranek and others, 2006). In areas to the north, similar conglomerates are interbedded with younger Eocene Challis Volcanic Group rocks (Snider and Moye, 1989; Snider, 1995; Skipp and others, 2009).

Throughout Eocene time and subsequently, volcanism and extension have dominated this region. Deformed Eocene Challis Volcanic Group rocks are unconformably overlain by Miocene volcanic rocks of the Idavada Volcanics that are themselves deformed. In the southwest corner of the map, Miocene ignimbrites (Tiv) are gently tilted southwest and faulted down against Paleozoic rocks. In the southeast corner of the map, flows are tilted southwards, either syn- or postdepositionally, towards the Snake River Plain. All the Miocene flows have sources within the Snake River Plain (Moye and others, 1988; Morgan and McIntosh, 2005; Kuntz and others, 2007). Deformation of the Miocene ignimbrites (Tiv) was followed by extensional faulting that began in the lower valley of Fish Creek where middle Pleistocene deposits are down faulted against the Wood River Formation. Middle Pleistocene alluvial deposits also are preserved in the West Fork of Fish Creek, but are absent in the upper channel of Fish Creek to the northeast. Normal faulting that borders the upper channel has a left lateral component and is buried by upper Pleistocene to Holocene alluvial deposits. No evidence for older alluvial deposits is present in that eastern channel. Faulting along the eastern valley continues northward into the upper reaches of Fish Creek (Skipp and others, 2009). The West Fork of Fish Creek may have its origins in the older Muldoon Creek drainage north and west of this quadrangle (Kuntz and others, 2007; Skipp and others, 2009). Upper(?) Pleistocene basalt of the Snake River Group erupted from a vent near the junction of the main and west forks of Fish Creek south of the reservoir. This basalt flow extends down the lower valley of Fish Creek onto the Snake River Plain (Kuntz and others, 2007). Basalts as young as about 2,000 years B.P. crop out along the Great Rift zone of the Craters of the Moon National Park located southeast of the quadrangle (fig. 1; Kuntz, and others, 1988; Kuntz, and others, 2007; Skipp and others, 2009).

The region is still extending tectonically within the seismic parabola of the Intermountain seismic belt (Scott and others, 1985; Pierce and Morgan, 1992; Janecke, 2007). The 1983 Borah Peak (BP) earthquake is recent evidence of continued Holocene basin-range extension in the region. The projected hypocenter of that earthquake is located at or just above the northern border of the map area of figure 1 (Haller and Crone, 2004).

Mineralization of the Wood River Formation, the base-metal-bearing gossan mapped in the southwestern window, is questionably attributed to recirculated mineralladen fluids that accompanied the intrusion of the Neogene or Cretaceous(?) stock identified at shallow depths in Long Canyon, and hypothesized to possibly underlie the window of carbonate rocks to the northeast. Otto and Zieg (2003) proposed an Ordovician age and source for these base-metal occurrences, although the Ordovician source is probable, the age of emplacement is not. The gossans are associated primarily with carbonate rocks of the Pennsylvanian Hailey Member (Pwh) of the Wood River Formation. Some of the western-facies Ordovician rocks are base-metal bearing (Otto and Zieg, 2003). Minor Au and Ag concentrations are reported in carbonate rocks of the Roberts Mountains Formation (DSrm) east of the Fish Creek Reservoir, and $\mathrm{Cu}$, $\mathrm{Zn}$, and As anomalies have been reported in carbonate rocks south-southeast of Timber Butte Springs in the southeastern part of the window east of Fish Creek (J.D. Loghry, written communications from 1984 to Feb. 21, 1988). Precious metals have been recovered from Challis Volcanic Group rocks in nearby areas (Nelson and Ross, 1969, 1970; Skipp and others, 2009), but none have been reported in this area. Hot springs located adjacent to the southeastern corner of the quadrangle indicate potential sources of geothermal energy along margins of the Snake River Plain.

\section{Acknowledgments}

This manuscript was reviewed by Paul K. Link of Idaho State University and Mitchell W. Reynolds of the U.S. Geological Survey. Their comments concerning interpretations of map relationships improved the map and manuscript immeasurably. 


\section{Description of Map Units}

\section{Surficial Deposits}

QI

$\mathrm{Qa}$

Qls

Qafc

Qc

Qaf2

Qao

Qaf3

Lacustrine deposits (Holocene) - Silt, clay, and minor sand, well sorted, thin bedded and parallel bedded. Thickness less than $1 \mathrm{~m}$, present in areas surrounding Fish Creek Reservoir

Alluvium of Fish Creek drainage (Holocene and late Pleistocene) - Silty sand to clayey silt, minor angular to rounded gravel; locally humic; nonbedded to parallel bedded in upper part. Pebble and cobble gravel in lower part is parallel bedded and includes large- and small-scale crossbeds. Locally includes fan alluvium and colluvium (Qafc) along valley margins and minor lacustrine deposits near reservoir. Low-lying areas are subject to periodic flooding, high water tables, and poor drainage. Unit description adapted from Scott (1982). Maximum exposed thickness about $8 \mathrm{~m}$

Landslide deposits (Holocene and late and middle Pleistocene) - Pebble- to boulder-sized, largely angular to subangular detritus; commonly contains silty sand to silty clay matrix, and largely intact small to large slide blocks of locally derived bedrock. Unit is nonsorted to poorly sorted, and nonbedded to crudely bedded. Unit chiefly includes deposits of avalanches and slumps of local derivation, but earthflows, debris flows, and mudflows are also included; deposits are more common on volcanic units, though one large slump of conglomerate of Copper Basin Group forming hill 5862 on the west-northwest side of Pine Mountain (NW 1/4 NE 1/4 sec. 14, T. 1 N., R. 22 E.) is notable because it previously was assigned to Copper Basin Group bedrock in Skipp and Hall (1975) and Kuntz and others (2007). Entire unit is characterized by irregular fragments forming hummocky, undrained topography, and has been subjected to major mass movements and small internal slumps. Unit description partly from Scott (1982)

Alluvial and colluvial fan deposits (Holocene and late and middle Pleistocene)-Pebble to boulder gravel, contains matrix of silty sand to clayey silt, poorly sorted, nonbedded to crudely bedded. Locally derived clasts are mostly angular to subrounded. Forms fans at mouths of smaller drainage basins. Unit description adapted from Scott (1982)

Colluvium (Holocene and Pleistocene) - Variably textured colluvium derived from nearby bedrock. Includes: (1) nonbedded to crudely bedded, coarse, angular to subrounded, gravel-size clasts with variable amounts of fine-grained matrix in colluvial cones and fans, and talus cones in rugged terrain developed on bedrock; and (2) sand, silt, and minor angular to subrounded fine gravel with variable amounts of fine-grained matrix; nonbedded to crudely bedded, that occur as unsorted talus and slumps present in gentle terrain formed on volcanic and intrusive rocks; unit includes rubbly colluvium along canyon walls. Thickness generally 1-3 m, but exceeds $10 \mathrm{~m}$ at base of slopes and in colluvial cones and fans. Unit description adapted from Scott (1982)

Fan alluvium 2 (late Pleistocene) - Pebble to cobble gravel, locally bouldery near fan heads, generally clast supported; contains variable amounts of sand to silty sand as matrix and small lenses; clasts subangular to subround, parallel bedding and large-scale crossbedding. Unit forms small remnants along upper reaches of West Fork of Fish Creek; characterized by thin or discontinuous caliche coats on clasts. Unit description from Scott (1982). Topographic position suggests a Pinedale age

Old alluvium (middle and early(?) Pleistocene) — Pebble to cobble gravel, locally bouldery, contains variable amounts of sand to silty sand matrix, some lenses of sand and silty sand, poorly to moderately sorted; clasts are subangular to round and are composed chiefly of Copper Basin Group and lesser volcanic rock fragments; includes basalt boulders in SW 1/4 sec. 32, T. 2 N., R. 22 E. Unit locally is crudely bedded, has medium to thick beds, and forms erosional remnants above small drainages on central west margin of quadrangle. These outcrops are located at heads of minor drainages that feed into Muldoon Creek west of this quadrangle (Kuntz and others, 2007). Unit is characterized by topographically high position above Muldoon Creek, by moderately well-developed soil, and 2-10 mm thick caliche coats on clasts. Thickness as much as $30 \mathrm{~m}$. Topographic position above Muldoon Creek (Kuntz and others, 2007) suggests a Bull Lake age

Older fan alluvium (middle and early(?) Pleistocene) - Pebble to cobble gravel, locally bouldery near fanheads, contains variable amounts of sand to silty sand matrix, some lenses of sand and silty sand, and is poorly to moderately sorted. Subangular to rounded clasts are largely composed of detritus from the Copper Basin Group, and include rare clasts of Wood River Formation. Minor amounts of felsic to mafic volcanic rock fragments are also present. Deposits have parallel beds and large-scale crossbeds, but locally are crudely bedded. Unit forms inclined fan remnants near mouth of Fish Creek and 
in upper reaches of West Fork of Fish Creek. Characterized by topographically moderate positions, as much as $50 \mathrm{~m}$ above level of Fish Creek, moderately well-developed soil, and 2- to 10-mm-thick caliche coats on clasts. Unit includes pediment gravel. Unit description adapted from Scott (1982). Topographic position suggests a Bull Lake age for most of unit, but pediment gravel may be early Pleistocene age. Unit as much as 125 -m thick

\section{Basalt Lava Flows}

\section{Craters of the Moon Volcanic Field}

Qcfg2

Qsbd2

Tiv

Carey pahoehoe and aa basalt-hawaiite flows (upper Pleistocene) —Chiefly surface- and tube(?)-fed, hummocky, medium-dark-gray pahoehoe basalt-hawaiite flows. Flow contains conspicuous ridges, plateaus, collapse pits, and depressions of various sizes, which are characteristic of high-volume, short-duration eruptions. Rock is hypocrystalline, medium to fine grained (mostly $<0.2 \mathrm{~mm}$ ), diktytaxitic, and microporphyritic. In typical samples, crystals of euhedral olivine (about $\mathrm{Fa}_{40-50}$ ), laths of plagioclase $\left(\mathrm{An}_{40-50}\right)$, and an equant, skeletal opaque mineral are as large as $0.8 \mathrm{~mm}$. Phenocrysts are set in a matrix of the same minerals plus a feathery, bladed opaque mineral, blades and patches of spindly, subophitic clinopyroxene, and granules of an equant opaque mineral, all $0.05-0.2 \mathrm{~mm}$, and opaque-charged, brown glass (Kuntz and others, 2007). Present in southeast corner of quadrangle

\section{Snake River Group}

Basaltic pahoehoe flows, pyroclastic deposits, and vent crater of Fish Creek Reservoir (inferred to be lower middle Pleistocene) - Dark-gray to medium-dark-gray, slightly weathered, vesicular, pahoehoe flow; vesicles commonly are filled with light-yellowish-orange caliche or silt. Unit locally covered by discontinuous deposits of loess and eolian sand (unmapped). Rock is typically hypocrystalline, fine grained, diktytaxitic, and porphyritic. Small sparse phenocrysts of labradorite are set in a groundmass of plagioclase, clinopyroxene, orthopyroxene, olivine, opaque minerals, and a small amount of clear glass (Skipp and Hall, 1975; Kuntz and others, 1988; Kuntz and others, 2007). Vent for flow lies a few hundred meters southeast of Fish Creek Reservoir dam. Approximate northern extent of flow in southern part of reservoir indicated by dotted line. Flows dissected to a depth of about $10 \mathrm{~m}$ directly south of dam. Total thickness unknown

\section{Idavada Volcanics (Miocene)}

Rhyolitic ignimbrites - Vitric-crystal, crystal-vitric, and lithic-crystal tuffs and minor interbedded polymictic alluvial gravel. Ignimbrites are grayish red, moderate reddish brown, moderate brown, dark yellowish brown, and black, and weather to similar colors. Tuffs are densely welded to nonwelded, porphyritic to glomeroporphyritic. Total phenocryst/crystal content ranges from 2 percent to 15 percent and includes feldspar, sanidine, and plagioclase, chiefly oligoclase-andesine, pyroxene, opaque iron oxides, and rare hornblende, biotite, and quartz in a brown glass groundmass; black vitrophyre zones locally are perlitic; lithic-rich layers contain pumiceous and non-pumiceous vitric clasts. A minimum of five emplacement units consist of multiple cooling units from coeval vents on the Snake River Plain (Moye and others, 1988). Ignimbrites are thick bedded to platy, have common zones of lithophysal cavities as much as $30 \mathrm{~cm}$ in length, have local flow lineations defined by elongation of vesicles, display rheomorphic-flow features, and vary in thickness from $0-150 \mathrm{~m}$. Thin $(<4 \mathrm{~m})$ polymictic alluvial gravel composed of angular to rounded pebble- to boulder-sized clasts derived chiefly from Copper Basin Group (Mississippian) and a lesser component of volcanic rocks from Challis Volcanic Group are cemented by an ash matrix. Gravel grades upward into very light-gray or yellowish-gray bedded, locally unconsolidated ash deposits present in places between cooling units and at base (Tig). Radiometric $\left({ }^{40} \mathrm{Ar} /{ }^{39} \mathrm{Ar}\right)$ ages on sanidine and volcanic glass in Lake Hills adjacent to quadrangle on west (Kuntz, Skipp, and Moye, 1994; Kuntz and others, 2007) range from $8.8 \pm 0.04$ Ma to $<11.0 \pm 1 \mathrm{Ma}$ for rhyolite ignimbrites. Flow near summit of Pine Mountain was inadvertently left off Craters of the Moon map (Kuntz and others, 2007), but a sample of basal vitrophyre of this flow (F-5) has been dated radiometrically $\left({ }^{40} \mathrm{Ar} /{ }^{39} \mathrm{Ar}\right)$ on single crystal sanidines at $9.23 \pm 0.03 \mathrm{Ma}$ (L.A. Morgan and W.C. McIntosh, written commun., 2011). Local springs issue from contacts between flows and 
unconformable basal contact with Challis Volcanic Group. Differences in elevations among outcrops of this unit indicate periods of uplift, doming, and faulting between periods of emplacement. Maximum total estimated thickness is $185 \mathrm{~m}$ (Skipp and others, 2009)

Gravel-Pebble- to boulder-sized polymictic alluvial gravel at base and within lower part of Idavada Volcanics (Tiv) mapped separately west and north of Long Canyon. Subrounded to angular boulders and cobbles of Copper Basin Group are primary constituents. A fan-shaped deposit with these characteristics resting on Idavada Volcanics at altitude 6,700-7,100 ft on north flank of Pine Mountain above Fish Creek is assigned to this unit with question

\section{Jasperoid}

Jasperoid (Oligocene(?) and Eocene(?)) - Medium-gray to black aphanitic to fine-grained silica formed by secondary silicification of mudstone of Copper Basin Group. One outcrop mapped on peak 6667 south of Payne Creek (N 1/2 SW 1/4 sec. 19, T. 23 E., R. 1 N.)

\section{Gossan}

Gossan (Miocene and post-Permian) —Dark-yellowish-brown, moderate-brown weathering, massive hematite, limonite, silica, and plumbojarosite, containing laminations of quartz sand, silt, and clay. Forms ledges and irregular knobs as thick as $15 \mathrm{~m}$ (Bruce Otto, consultant, Boise, Idaho, written communication, 1992). Gossan is interpreted in this report to be chiefly an alteration product of impure limestone of the Hailey Member of Wood River Formation. Otto and Zieg (2003) consider the gossan to be related to mineralized layers in the Phi Kappa Formation (SOp). Source for sulfides, iron, and other minerals identified in the gossan probably is Tertiary to Cretaceous(?) biotite granodiorite intrusion (TKbg) encountered at $61 \mathrm{~m}$ below surface in drill hole LC-3 in Long Canyon (Otto and Zieg, 2003). Hydrothermal fluids injected along normal faults may have concentrated minerals along unconformity between Pennsylvanian limestone and older Paleozoic siltstone and mudstone.

\section{Challis Volcanic Group (Eocene)}

Dikes-Moderate-grayish-pink, pinkish-gray, and very light to light-gray rhyolitic breccia contains angular to subangular fragments of volcanic rocks, mainly devitrified glass, quartz and feldspar altered to chalcedony and clay, respectively, and a few angular fragments of fine-grained siliceous sedimentary rocks set in a groundmass of altered quartz and feldspar. Rare mafic phenocrysts that include hornblende are altered to opaque iron oxides. Breccia fragments are chiefly granule size, but locally range from silt to boulder sizes. Dikes weather moderate brown. Trends of dikes are generally north and north-northeast. Dikes intrude Copper Basin Group and andesites (Tca) in quadrangle, but cut associated intrusive rocks $3 \mathrm{~km}$ east of quadrangle (Sidle, 1979; Kuntz, Skipp, and Moye, 1994; Moye and others, 1995)

Latitic ignimbrite of Stoddard Gulch - Crystal-lithic latitic ignimbrite, grayish red, moderate brown, light olive gray with light-brown fragments, and dark gray to black; weathers to similar colors; nonwelded to densely welded; porphyritic; total phenocryst/crystal content is as much as 25 percent and includes feldspar, chiefly zoned and twinned plagioclase, oligoclase to labradorite, biotite, pyroxene, and opaque iron oxides, and as much as 20 percent volcanic lithic fragments, some vitric. Dark-gray to black vitrophyre zones, locally perlitic, contain both pumiceous and non-pumiceous vitric clasts. Tuff of Stoddard Gulch is a multiple cooling unit, is chiefly thick bedded, and locally has zones of lithophysal cavities a few $\mathrm{cm}$ in length. Within quadrangle, unit is as thick as about $85 \mathrm{~m}$. Tuff unconformably overlies dacite flows of Challis Volcanic Group (Tcd) in northwest corner of quadrangle, and is unconformably overlain by Miocene ignimbrites of Idavada Volcanics (Tiv). Near type section in Stoddard Gulch $20 \mathrm{~km}$ to the northeast (Skipp, 1989), tuff yielded an age of $47.37 \pm 15 \mathrm{Ma}$ on biotite using ${ }^{40} \mathrm{Ar}{ }^{39} \mathrm{Ar}$ methods (Moye and others, 1995; Snider, 1995)

Dacite flows, domes, and interbedded ignimbrite - Brownish-gray, pale-brown, grayish-red, mediumgray, and pale-yellowish-brown dacite flows and intrusions that weather moderate brown and dark yellowish brown. Dacite is porphyritic, total phenocryst/crystal content ranges from 15-40 percent; phenocrysts include feldspar, chiefly plagioclase, biotite, hornblende, pyroxene and minor quartz set in a finely crystalline groundmass of mainly feldspar and quartz. Plagioclase laths as long as $7 \mathrm{~mm}$ 
Tcat

Tcac

Tcar

Tca

Tcrt

Tcc are twinned and zoned, range in composition from andesine to labradorite $\left(\mathrm{An}_{30}-\mathrm{An}_{55}\right)$, and make up as much as 30 percent of the rock. Mafic phenocrysts commonly are rimmed with or replaced by opaque iron oxides. Flows and intrusions commonly are banded and form ridges. Local hydrothermal alteration has altered rock to a soft, very light-gray breccia rich in clay minerals and secondary silica. Ignimbrite (Tcat) is interbedded in secs. 7, 17, 18 T. 1 N., R. 22 E. Thickness ranges from 90 to 200 $\mathrm{m}$. Overlain unconformably by latitic ignimbrite of Stoddard Gulch (Tcls) or Idavada Volcanics (Tiv). Rests unconformably on or intrudes andesite flows and dikes (Tca)

Dacitic ignimbrite - Pale-red, grayish-red, brownish-gray and black vitric-crystal biotitic tuff that is moderately to densely welded and locally brecciated. Total phenocryst/crystal content is about 25 percent and includes zoned and twinned plagioclase crystals, chiefly andesine to labradorite, 2-7 percent biotite commonly rimmed or replaced with opaque iron oxides, less than 1 percent pyroxene and quartz, and rare lithic fragments in a brown glass groundmass containing common flattened pumice fragments. Compacted yellowish-gray, fine-grained ash that contains 2 percent biotite is included in this unit. Thickness $0-37 \mathrm{~m}$ from east to west in dacite flows (Tcd) or unconformably overlain by Idavada Volcanics (Tiv)

Tuff of Antelope Creek - Grayish-orange, dusky-yellow-green, olive-gray, and light-gray to black, nonwelded to densely welded andesitic to latitic ignimbrite, devitrified and vitrophyric, variable pumiceand lithic-rich, multiple compound cooling units. Total phenocryst/crystal content in one thin section is about 20 percent and includes 5-10 percent plagioclase, 5 percent basic volcanic lithic fragments, 3 percent opaque minerals, 2 percent pyroxene, and rare biotite in a dark-brown glassy matrix composed of flattened pumice fragments. Regional thickness approximately 0-550 m. Outcrop extends into quadrangle to north (Skipp and others, 2009)

Andesitic vitric-crystal tuff and tuff breccia-Yellowish-gray, brownish-gray, and black, banded and locally brecciated fine-grained porphyritic vitric-crystal tuff. Total phenocryst/crystal content ranges from 10 percent to 40 percent and includes small, less than $0.1 \mathrm{~mm}$ long, phenocrysts of zoned and twinned andesine to labradorite feldspar, and 0 to 10 percent pyroxene, chiefly altered to a brown fibrous mineral, in a devitrified or glassy groundmass. Thickness of bands and layers varies from less than $1 \mathrm{~mm}$ to several $\mathrm{cm}$. Layers locally exhibit a rough horizontal bilateral symmetry with mafic minerals concentrated in center of layer. Breccias and structures resembling crossbeds and cut-andfill structures are common. A small outcrop of a pale-red vitric tuff that is not banded is present in SW $1 / 4$ sec. 22 , T. 2 N., R. 22 E. Isolated breccia zones in vicinity of this tuff contain small to large fragments of it. Unit has many characteristics of a pyroclastic surge deposit (Wohletz and Sheridan, 1979). Stratigraphic position unclear; may intrude unit Tca. Estimated thickness 0 to about $150 \mathrm{~m}$

Andesite flows and dikes - Medium- to dark-gray, grayish-black, brown, and grayish-brown andesite flows and dikes that have characteristic thin to thick weathered rinds of pale brown, moderate brown, and moderate yellowish brown. Andesites are porphyritic to glomerophyritic. Total phenocryst/crystal content ranges from 10 percent to 25 percent and includes both clinopyroxene and orthopyroxene, or hornblende, opaque iron oxides, zoned and twinned plagioclase, chiefly labradorite and andesine, and minor biotite in a finely crystalline groundmass of feldspar, pyroxene, opaque iron ores, and quartz. Olivine-bearing andesite is rare. Hornblende-bearing andesite is common only in northern part of quadrangle. Rhyolitic lithic-crystal tuff (Tcrt) locally is interbedded with basal andesite flows in Mints Canyon in southern part of quadrangle, and a plagioclase-rich banded unit (Tcar), possibly a basesurge deposit, is present in lower part in northwest part of quadrangle. Thickness varies from about 60-250 m. Unit rests on Paleozoic rocks and locally is overlain or intruded by dacite flows or domes (Tcd) or is overlain by Idavada Volcanics (Tiv)

Rhyolitic lithic-crystal tuff - Grayish-yellow-green, yellowish-gray, and light-olive-gray tuff weathers light brown and moderate brown. Tuff consists of as much as 50 percent volcanic lithic fragments, chiefly devitrified; 20 percent zoned and twinned plagioclase, chiefly oligoclase; 5 percent biotite; 5 percent hornblende; and 1 percent quartz in a devitrified glassy groundmass. Tuff forms steep slope beneath andesite (Tca) in Mints Canyon on southern edge of quadrangle. Minimum thickness in Mints Canyon is $91 \mathrm{~m}$

Smiley Creek formation (informal unit of Paull, 1974) - Pebble to boulder conglomerate containing minor interbeds of very coarse- to granule-sized quartz sandstone. Conglomerate, light gray to medium gray; weathers moderate brown to dark yellowish brown; clasts are locally derived chiefly from Copper Basin Group, rounded, commonly $6-10 \mathrm{~cm}$ in diameter, and consist of 70-80 percent fine- to medium-grained, medium-gray to very light-gray quartzite, 5-15 percent moderate-yellowish-brown 
and pale-brown argillite, and 10 percent medium-light-gray siltstone; matrix is coarse-grained, silicacemented quartz and chert sand that also makes up sandstone interbeds. Unit is thick bedded to poorly bedded; cementation variations cause clasts to break out of unit in places and to break across clasts in others. Outcrops locally weather to form pillars and tunnels. Unconformably overlies Paleozoic rocks and is disconformably overlain by volcanic rocks (secs. 23, 31, 32, T. 2 N., R. 23 E.) Thickness ranges from 0 to $33 \mathrm{~m}$ (Larson, 1974). Present as erosional remnants mainly east of Fish Creek. Inferred to have been deposited as an alluvial fan complex (Paull, 1974; Burton and Blakely, 1988)

\section{Intrusive Rocks}

TKbg

Biotite granodiorite (Tertiary and Late Cretaceous(?)) - (Shown only on cross sections) Light- to mediumlight-gray, medium-grained, equigranular to porphyritic granodiorite, contains 75 percent plagioclase and quartz in equal amounts, 10-15 percent potassium feldspar, and 2-percent biotite books up to 4-mm thick. Plagioclase is twinned and zoned oligoclase to andesine and is partly altered to sericite and clay; biotite is replaced with chlorite. Minor hornblende may have been present, but is now also replaced by chlorite. Pyrite, chalcopyrite, sphalerite, and molybdenite are present in trace amounts (adapted from Otto and Zieg, 2003). Thick biotite books are characteristic of Cretaceous plutons (Kdgk) in southeastern part of Atlanta lobe of Idaho batholith dated at about $85 \mathrm{Ma}$ on geologic maps of Worl and others, 1991, and Worl and Johnson, 1995. A Neogene age seems more likely, however, as the Idavada Volcanics of Miocene age are faulted in area surrounding horst in which it was drilled. Mineral content of pluton does not preclude a Neogene age. Granodiorite was encountered at $55 \mathrm{~m}$ in drill hole LC-3 near the mouth of Long Canyon. It intrudes Lower Paleozoic rocks of horst. Approximate location of drill hole is $\mathrm{S} 1 / 2 \mathrm{NE} 1 / 4 \mathrm{SE} 1 / 4 \mathrm{sec}$. 29 , T. 1 N., R. 22 E., or lat. $43^{\circ} 23^{\prime} 18^{\prime \prime}$ N., long. $113^{\circ} 51^{\prime} 17^{\prime \prime}$. On cross sections $B-B^{\prime}$ and $C-C^{\prime}$, biotite granodiorite also is hypothesized to intrude lower Paleozoic carbonate rocks upraised within a horst located several miles northeast of drill hole.

\section{Pre-Mesozoic Sedimentary Rocks}

\section{Hanging Wall of Pioneer Thrust Fault}

PPweu

Pwel

\section{Wood River Formation (Lower Permian and Upper and Middle Pennsylvanian) Eagle Creek Member (Lower Permian and Upper Pennsylvanian)} Upper part (Lower Permian and Upper Pennsylvanian) - Siliceous sandstone, calcareous sandstone, sandy limestone, and minor conglomerate and siltstone. Siliceous sandstone, light brown, very light to medium gray, very fine to medium grained (grains 0.04 to $0.4 \mathrm{~mm}$ in diameter); consists of angular to subrounded quartz grains with sutured contacts, and accessory chert, sericite, zircon, amphibole, and altered feldspar; weathers moderate brown, medium gray, and light olive gray, and is medium to thick bedded; locally laminated and brecciated (sedimentary breccias are dominant, but tectonic breccias also present). Calcareous sandstone and sandy limestone, brown to medium gray, fine grained; consists of subrounded grains of quartz and accessory components similar to siliceous sandstone; fineto medium-grained, chiefly bioclastic, calcite matrix containing minor sericite and cryptocrystalline quartz; weathers brown and reddish brown; medium to thick bedded. Conglomerate interbedded with siliceous sandstone only east of Fish Creek in lower $150 \mathrm{~m}$ of unit; contains granule- to pebble-sized clasts of chert, quartz, and quartzite as much as $1.5 \mathrm{~cm}$ in diameter in a siliceous or sericitic matrix; beds are graded, laminated, and internally deformed. Distinctive rare siltstone is light greenish gray and platy. Gradational lower contact. No diagnostic fossils have been recovered from unit in this area. Unit forms ledges and talus-covered slopes. More than $600 \mathrm{~m}$ thick in Fish Creek area. Correlates with units 5 and 6 of Wood River Formation of Hall and others (1974) and with upper part of Eagle Creek Member of Mahoney and others (1991). Description modified from Link and others (1995), Skipp and Hall (1975), and Larson (1974)

Lower part (Upper Pennsylvanian) - Interbedded sandy limestone, calcareous sandstone, and granule to pebble conglomerate in upper part; calcareous siltstone and mudstone, and noncalcareous mudstone in lower part. Limestone and calcareous sandstone of upper part is medium gray to medium dark gray and weathers the same colors; contain very fine to coarse-grained angular to rounded quartz grains, lithic fragments, and accessory feldspar, zircon, sericite, and hornblende in a micritic 
or bioclastic limestone matrix; commonly laminated; medium to thick bedded; graded beds common. Conglomerate, medium gray; clasts are angular to subrounded fragments as much as $5 \mathrm{~cm}$ in diameter but mostly smaller, of black, gray, and yellow chert, light-gray quartzite, spicular limestone, and minor dark-gray and yellow argillite; limestone or siliceous sandstone matrix; clast-supported textures common; forms lowest part of graded sequences; medium to thick bedded; forms ledges and slopes. Conglomerate composes as much as 40 percent of this part of Eagle Creek Member east of Fish Creek, and less than 10 percent of same unit west of Fish Creek (Skipp and Hall, 1975). Siltstone and mudstone of lower part of member are pale red and pale reddish purple; thin to medium bedded, forms slopes; measured thickness in NE 1/4 sec. 22, T. 1 N., R. 22 E. is $61 \mathrm{~m}$; conformable contact with underlying Hailey Member (Pwh). Unit veined with quartz in thrust remnant just southeast of basalt vent area on east side of Fish Creek. Unit contains fusulinids, pelmatazoan, bivalve, molluscan, bryozoan, and coralline debris (Skipp and Hall, 1975); correlates with units 3 and 4 of Wood River Formation of Hall and others (1974) and lower part of Eagle Creek Member (Mahoney and others, 1991; Link and others, 1995). Estimated total thickness $350 \mathrm{~m}$

Hailey Member (Middle Pennsylvanian) — Limestone, sandy limestone, calcareous sandstone, interbedded conglomerate, and minor thin beds of dark-gray mudstone that weathers pale reddish purple. Limestone, medium gray to medium dark gray, weathers the same colors; micrite and fine- to mediumgrained oolite-intraclast grainstone to packstone. Sandy limestone and calcareous sandstone are similar to rocks described in lower part of Eagle Creek Member (Pwel). Conglomerate is similar to that in Pwel except clasts are generally larger, as much as $10 \mathrm{~cm}$ in diameter, and graded beds are absent. Unit is thin- to thick-bedded; forms cliffs and low ledges; contains sparse fusulinids and other fossils (Skipp and Hall, 1975); correlates with units 1 and 2 of Wood River Formation of Hall and others (1974). Altered to gossan $(\mathrm{Tg}$ ) in upraised block in southwestern corner of quadrangle (see discussion in section on mineral deposits). Rests with angular unconformity on, or is faulted against, lower Paleozoic siltstone and mudstone assigned to Phi Kappa Formation, Trail Creek Formation, and associated beds (DSs and SOp of this report). Maximum exposed thickness about $200 \mathrm{~m}$

\section{Footwall of Antler-age Thrust Fault}

Siltstone (Devonian(?) and Silurian) --Medium-gray, brownish-gray, and light-olive-gray dolomitic and calcareous siltstone, very fine-grained sandstone, and minor sandy limestone; weathers moderate brown, light brownish gray, and grayish red; thin-bedded and laminated; bedding commonly obscured by well-developed cleavage nearly parallel or at a low angle to bedding; weathers to slabs containing abundant trace fossils ("worm trails" of Dover, 1981, 1983); no other fossils recovered. Unit closely resembles buff-weathering, limy to dolomitic siltstone with wispy laminations of Dover's (1981) unnamed Silurian and Devonian unit in Pioneer Mountains about $40 \mathrm{~km}$ northwest of Fish Creek Reservoir; estimated exposed thickness $200 \mathrm{~m}$. Present only in Long Canyon-Mints Canyon area

\section{Hanging Wall of Antler-age Thrust Fault}

Trail Creek Formation (Silurian) - Sandstone, siltstone, and minor limestone; sandstone and siltstone, medium- to fine-grained; pale-yellowish-brown to medium-dark-gray quartzose sandstone; quartz grains chiefly subangular to subrounded; iron-oxide grains and cement common, silica and (or) calcareous cement also common; banded, darker bands have higher iron-oxide content than light bands; unfossiliferous. Sandstone lenses, either sedimentary or tectonic, form ledges in gray shaly siltstone. Outcrop veined with quartz. One or two unfossiliferous limestone lenses included in upper exposures. Lower contact conformable with medium-gray-weathering shaly siltstone assigned to Phi Kappa Formation (SOp). Estimated minimum thickness $20 \mathrm{~m}$. Overlain unconformably by Hailey Member (Pwh) of Wood River Formation. Mapped only on ridge between Long and Mints Canyons silicified, chert, siltstone, sandstone, minor granule conglomerate, and silicified limestone. Upper part mainly dark-gray argillite and siltstone but includes chert, conglomerate, and silicified limestone. Argillite and siltstone, chiefly dark gray, carbonaceous, locally oxidized to light gray; weathers pale brown and moderate brown, local silvery phyllitic sheen; thin bedded to banded; local load casts, graded beds, crossbeds; tight folds, cleavage subparallel to bedding; locally graptolitic; poorly preserved 
graptolites identified by Claire Carter (U.S. Geological Survey, written communs., 1988, 1991) include Climograptus sp., Glyptograptus? sp., Orthograptus? sp., and Glossograptus? sp. (fossil collection F-2) of probable Middle Ordovician age collected from mine dump (Otto and Zieg, 2003) and prospect pit 100 m north-northeast of mine dump on east side of Long Canyon (fossil collections F-1 and F-2); and Orthograptus cf. O. amplexicaulis (Hall), Climograptus cf., C. tubuliferus (Lapworth), C. cf. C. hastatus T.S. Hall, Glyptograptus? sp., and Amplexograptus? sp. of probable Late Ordovician age collected from float on west side of Long Canyon (fossil collections F-3 and F-4). Limestone, silicified, banded medium light gray to dark gray; weathers grayish orange, thin bedded; rare on slope beneath Trail Creek Formation (St). Chert, ferruginous chert, and siliceous argillite, dark gray, grayish red, and moderate brown; weathers same colors or light to yellowish gray, laminated or thin bedded to thick bedded; forms cliffs; blocky to chippy talus; locally highly foliated dark-gray argillite in bottom of Long Canyon exhibits abundant small, tightly folded quartz veins. Unit also contains stratigraphically controlled gossan (Tg) associated with thin- to thick-bedded chert (Og and Oc of Otto and Zieg (2003)]. Sandstone, medium dark gray; weathers medium dark gray to moderate brown; very fine to medium grained, siliceous cement, thick-bedded; forms ledges. Granule conglomerate, medium gray; weathers brown, interbedded with siliceous sandstone. Sandstone and granule conglomerate resemble basal Basin Gulch Quartzite Member of Phi Kappa Formation (Dover, 1981, 1983). Base not exposed; unit intruded by biotite granodiorite $55 \mathrm{~m}$ below surface in Long Canyon (Otto and Zieg, 2003). Gradationally overlain by Trail Creek Formation (St) or unconformably overlain by Hailey Member (Pwh) of Wood River Formation. Entire unit folded both megascopically and microscopically. Estimated minimum thickness $210 \mathrm{~m}$

\section{Footwall of Pioneer Thrust Fault}

\section{Copper Basin Group (Mississippian)}

Mcb

Mca
Copper Basin Group undivided (Upper and Lower Mississippian) - Interbedded quartzite, argillite, siltite, conglomerate, and limestone turbidites divided into three formations, in descending order: Argosy Creek Formation, Drummond Mine Limestone, and Little Copper Formation. Used on cross section and where identity of formation uncertain. Estimated minimum thickness 2,600 m

Argosy Creek Formation (Upper and Lower Mississippian) - Chiefly proximal and distal turbidites and interturbidites consisting of interbedded quartzite, argillite, siltite, and conglomerate, in order of decreasing abundance (Paull and others, 1972; Larson, 1974; Skipp and Hall, 1975; Nilsen, 1977; Link and others, 1996). Quartzite, very light to medium gray on fresh surfaces, weathers moderate to dark yellow brown, light olive gray, and pale brown; fine to coarse grained, commonly medium grained and well sorted; grains are angular to subrounded quartz (50-80 percent) and lithic fragments, chiefly chert and siltstone (10-40 percent) in a dominantly siliceous or sericitic matrix containing minor amounts of opaque iron oxides and carbonaceous material; quartz grains have common silica overgrowths, concavo-convex to sutured borders, and penetrate less competent lithic fragments. Quartzite is medium to thick bedded; locally graded, laminated, and crossbedded; load casts, sole markings, and ripple marks common; well-developed fracture cleavage; common gradational upper contacts; forms ledges and steep slopes. Argillite and siltite, dark gray to medium gray, weather light olive gray, moderate brown, and grayish brown; consist of 40-80 percent clay commonly altered to sericite, locally carbonaceous, 20-60 percent silt and fine-grained angular quartz clasts, and 5-15 percent very fine-grained chert clasts; laminated to thin bedded. Forms slope except where locally silicified to jasperoid (Tj). Conglomerate, light to dark gray, weathers pale brown, moderate brown, and grayish red; granule- to cobble-sized clasts as much as $20 \mathrm{~cm}$ in diameter, in descending order of abundance, varicolored (light to dark gray, light olive gray, grayish orange, dark yellowish orange), angular to subangular chert, subangular medium-dark-gray, light-gray, and grayish-orange argillite, light-brownish-gray siltstone, and subrounded to rounded light-gray quartzite that consistently makes up the largest clasts; matrix forms as much as 50 percent of rock and is medium- to fine-grained quartz sand, subangular to rounded chert, and argillaceous material cemented by silica and clay. Local 30-50 cm blocks of laminated argillite in random orientation indicate slumping; thick to very thick bedded, common graded bedding. Two brachiopod collections (USGS collections 25409-PC and 27118-PC) from a mudflow high in the section in $\mathrm{N}$ 1/2 NE 1/4 SE 1/4 sec. 33, T. 2 N., R. 23 E., east of this quadrangle suggest a late Meramecian or early Chesterian age (J.T. Dutro, Jr., written commun., 1978, 1993; F-1 in Kuntz, Skipp, and Moye, 1994, and 
in Kuntz and others, 2007). Conodonts from immediately above Drummond Mine Limestone (Mcd) in measured section are Kinderhookian (Skipp and Hall, 1975), as are conodonts from fossil locality F-1 of this report (F-2 of Kuntz and others, 1994; and F-3 of Kuntz and others, 2007). Trace fossils of Cruziana facies (Rhizocorallium) are present on surfaces of sandstone blocks near the top of type section (Link and others, 1996, p. 127). Gradational contact with Drummond Mine Limestone (Mcd) below; forms ledges and steep slopes; comprises Scorpion Mountain, Muldoon Canyon, and Brockie Lake Conglomerate Members in ascending order (Paull and others, 1972; Link and others, 1996). Estimated minimum thickness in area is 2,185 $\mathrm{m}$ (Larson, 1974)

Drummond Mine Limestone (Lower Mississippian) - Chiefly limestone turbidite (Paull and others, 1972; Nilsen, 1977) interbedded with calcareous sandstone and quartzite above Fish Creek Reservoir (Skipp and Hall, 1975) and argillite and chert near head of East Fork of Fish Creek (Larson, 1974). Limestone, medium to dark gray, pale red, and yellowish brown, weathers dark yellow orange, pale yellowish brown, medium light gray, and light olive gray; aphanitic to conglomeratic, micrite including spiculite and biomicrite, and as much as 40 percent argillaceous and carbonaceous material, and intramicrite containing clasts of micrite as much as $7 \mathrm{~mm}$ in diameter and fossil fragments in a lime mud matrix; thin to medium bedded $(0.2-0.8 \mathrm{~m})$. Sandstone, medium gray to light brown, calcareous, fine grained, and quartzite, dark gray, laminated, $1.5 \mathrm{~m}$ thick near base of unit above Fish Creek Reservoir. Argillite, grayish black to dark gray, interlaminated with chert, light gray, silty, argillaceous, weathers grayish orange to very pale orange. Forms low ledge. Limestone above Fish Creek Reservoir yielded Kinderhookian conodonts and foraminifers (Skipp and Hall, 1975). Gradational basal contact with Little Copper Formation (Mcl). Forms low ledges. Total measured thickness 34 m above Fish Creek Reservoir (Skipp and Sandberg, 1975)

Little Copper Formation (Lower Mississippian) - Chiefly turbidites consisting of interbedded light- to medium-dark-gray quartzite, grayish-black, brown, and pale-red mudstone and siltstone, and minor granule to cobble conglomerate, in decreasing order of abundance. Sandstone is fine grained to conglomeratic, laminated (alternating concentrations of dark chert and light quartz grains), locally graded, common load casts and scour-and-fill structures; grains are angular to well rounded and consist of quartz, chert, carbonaceous claystone, quartzite, and rare mica and epidote in a carbonaceous-clay matrix containing opaque iron oxides and common siliceous cement; weathers light gray, light brown, and pale yellowish brown; thin to thick bedded $(0.3-0.9 \mathrm{~m})$; forms ledges. Mudstone and siltstone weather light gray and light brown, calcareous in places, thin bedded to laminated; trace fossils, flattened coiled ammonoid, gastropod, and woody plant impressions rare on bedding surfaces. Ammonoids from near base probably Early Mississippian in age (Mackenzie Gordon, Jr., in Skipp and Hall, 1975). Conglomerate, light to dark gray, weathers pale brown and moderate brown; clasts as much as $8 \mathrm{~cm}$ in diameter of subangular to subrounded chert, quartz, and quartzite in a matrix of rounded quartz sand grains, commonly silicified; medium to thick and graded beds. Unit forms a thickeningand-coarsening upward sequence. Forms slopes and ledges. Disconformable lower contact with Picabo Formation (Dp) north of Fish Creek Reservoir is part of regional unconformity (Paull and Gruber, 1977; Skipp and Bollmann, 1992; Wilson and others, 1994: Link and others, 1996). Measured thickness $372 \mathrm{~m}$ above Fish Creek Reservoir (Skipp and Hall, 1975)

Picabo Formation (Upper Devonian) - Interbedded dolomitic sandstone, sandy dolomite, sandy dolomitepebble conglomerate, and minor calcareous sandstone. Dolomitic sandstone and sandy dolomite, medium light to dark gray, pale yellowish brown; weathers pale yellowish brown, medium dark gray to light gray, and light olive gray; chiefly fine grained; laminated, and medium to thick bedded; load casts common, crossbedding rare; forms ledges and steep slopes. Sandy dolomite-pebble conglomerate, medium light gray to pale yellowish brown; weathers chiefly pale yellowish brown; size of dolomite pebbles bimodal; larger pebbles well rounded, subtabular, as much as $12.5 \mathrm{~cm}$ in diameter; smaller pebbles average $6 \mathrm{~mm}$ in diameter, subrounded; both sizes are light gray to grayish black, aphanitic to coarsely crystalline (derived from underlying Jefferson Formation (Dj) and Carey Dolomite (Dc); matrix of conglomerate is fine- to medium-grained dolomitic quartz sandstone; thick bedded $(2-3 \mathrm{~m})$; forms ledges and steep slopes. Calcareous sandstone, light gray to pale red; weathers pale yellowish brown; very fine to fine grained, thin bedded, partly laminated, locally present at top of formation. No fossils have been recovered at this locality, but the formation may be equivalent to the Sappington Member of the Three Forks Formation (Skipp and Sandberg, 1975) of mostly latest Devonian age. The base of the formation is covered but appears to be concordant. Regional evidence, however, suggests that the base is an unconformity (Sandberg and others, 1975). Conodonts from near top of sandy 
dolomite assigned to this stratigraphically equivalent formation at Timbered Dome (Skipp and others, 1990; Skipp and others, 2009) about $10 \mathrm{~km}$ northeast of Fish Creek Reservoir are of latest Devonian (Famennian) age. Measured thickness at type section on ridge above Fish Creek Reservoir is $57.6 \mathrm{~m}$ (Skipp and Sandberg, 1975)

Dc

DSrm

$\mathrm{SOu}$

Jefferson Formation (Upper and Middle Devonian) —Dolomite and basal dolomite breccia and sandy dolomite conglomerate. Dolomite, medium gray to grayish black, pale yellowish brown, light brownish gray; weathers light olive gray, light gray to grayish black, and dark yellowish orange to pale yellowish brown; finely to coarsely crystalline, locally sandy and silty, locally laminated, locally vuggy; fossiliferous (conodonts, corals, brachiopods, stromatoporoids, and boney fish). Formation divided into six units not mapped here (Skipp and Sandberg, 1975), in descending order: 1) yellow vuggy dolomite, 2) banded dolomite, 3) black dolomite, 4) blue dolomite, 5) silty dolomite, all five above units deposited in a fluctuating intertidal and subtidal environment; and 6) basal dolomite breccia and sandy-dolomite conglomerate, medium gray; weather light gray to light olive gray; breccia clasts as much as $0.6 \mathrm{~m}$ in diameter; breccia merges along strike into undisturbed laminated dolomite and interbedded rounded dolomite-cobble conglomerate containing clasts that resemble rock types of the Carey Dolomite (Dc), as large as $12.7 \mathrm{~cm}$ in diameter in a quartz sand matrix. Entire formation deposited in tidal flat to shallow subtidal marine environments. Medium to thick bedded; forms ledges and steep slopes; unconformable basal contact. Composite measured thickness $245 \mathrm{~m}$ on north side of Fish Creek Reservoir (Skipp and Sandberg, 1975)

Carey Dolomite (Middle and Lower Devonian) - Light-gray to medium-dark-gray dolomite, minor dolomite sandstone, and granule to pebble conglomerate; weathers light gray, yellowish gray, and olive gray; medium to thick bedded $(0.3-3.0 \mathrm{~m})$; finely crystalline to aphanitic; common algal-mat laminae, birdseye porosity, mud-chip conglomerate, rare quartz sand and silt grains; sparsely fossiliferous (conodonts, corals, brachiopods, and crinoid ossicles). Early Middle Devonian (Eifelian) conodont faunas recovered from lower beds (Skipp and Sandberg, 1975); deposited chiefly in intertidal and supratidal, locally, low subtidal marine environments. Forms step-like ledges; base not exposed. Partial measured thickness of $147.8 \mathrm{~m}$ at type section on north side of Fish Creek Reservoir (Skipp and Sandberg, 1975)

Roberts Mountains Formation (Lower Devonian and upper Silurian) - Limestone and phenoplast conglomerate interbedded with calcareous siltstone and silty limestone. Upper part consists of phenoplast conglomerate or intraformational sedimentary limestone breccia composed of subangular to subrounded fragments, as much as $25 \mathrm{~cm}$ in diameter, of bioclastic limestone and encrinite; weathers medium gray, in yellowish-orange-weathering fossiliferous lime-mud matrix; medium bedded. Middle part is interbedded coral-reef limestone, silty limestone, and calcareous siltstone. Coralline limestone, medium gray, medium to coarse grained; medium bedded; siltstone, yellowish brown; weathers dark yellowish orange and light brown; irregularly dolomitized, platy. Lower part is coralline limestone, as above, interbedded with limestone encrinite, medium dark gray, coarse to very coarse grained, thin bedded. Formation is fossiliferous (corals, conodonts, gastropods, tentaculitids, trilobites, brachiopods, primitive calcareous benthic foraminifers, and calcareous blue-green algae). Formation forms ridge on east side of Fish Creek Reservoir; base and top faulted. Partial estimated thickness $200 \mathrm{~m}$ (Skipp and Sandberg, 1975)

Upper Silurian and Ordovician rocks, undivided, only in cross section $\boldsymbol{C}-\boldsymbol{C}^{\prime}-$ Quartzite, limestone, and dolomite including Kinnikinic Quartzite and Summerhouse Formation that crop out in a kipuka surrounded by basalt of Snake River Group in the southern Pioneer or White Knob Mountains northeast of quadrangle (Skipp and others, 2009) 


\section{References Cited}

Beranek, L.P., Link, P.K., and Fanning, C.M., 2006, Miocene to Holocene landscape evolution of the western Snake River Plain region, Idaho: Using the SHRIMP detrital zircon provenance record to track eastward migration of the Yellowstone hotspot: Geological Society of America Bulletin, v. 118 , no. 9/10, p. 1027-1050.

Burton, B.R., and Blakey, J.D., 1988, The basal Challis Conglomerate, Custer County, south-central Idaho: Implications for the initiation of Challis volcanism [abs.]: Geological Society of America Abstracts with Programs, v. 20 , no. 6 , p. $408-409$.

Dover, J.H., 1981, Geology of the Boulder-Pioneer wilderness study area, Blaine and Custer Counties, Idaho: U.S. Geological Survey Bulletin 1497-A, p. 1-75, scale 1:62,500.

Dover, J.H., 1983, Geologic map and sections of the central Pioneer Mountains, Blaine and Custer Counties, central Idaho: U.S. Geological Survey Miscellaneous Investigations Series Map I-1319, scale 1:48,000.

Hall, W.E., Batchelder, John, and Douglass, R.C., 1974, Stratigraphic section of the Wood River Formation, Blaine County, Idaho: U.S. Geological Survey Journal of Research, v. 2, no. 1, p. 89-95.

Haller, K.M., and Crone, A.J., 2004, Twenty years after the Borah Peak earthquake-Field guide to surface-faulting earthquakes along the Lost River fault, Idaho, in Haller, K.M., and Woods, S.H., eds., Geological Field Trips in Southern Idaho, Eastern Oregon, and Northern Nevada: Rocky Mountain and Cordilleran sections, Geological Society of America, annual meeting, Boise, Idaho, p. 116-134.

Janecke, S.U., 2007, Cenozoic extensional processes and tectonics in the northern Rocky Mountains - Southwest Montana and eastern Idaho, in Thomas, R.C., and Gibson, R.I., eds., Introduction to the Geology of the Dillon Area: Northwest Geology, v. 36, p. 111-132.

Kuntz, M.A., Champion, D.E., Lefebvre, R.H., and Covington, H.R., 1988, Geologic map of the Craters of the Moon, Kings Bowl, and Wapi lava fields, and the Great Rift volcanic rift zone, south-central Idaho: U.S. Geological Survey Miscellaneous Investigations Map I-1632, scale 1:100,000.

Kuntz, M.A., Skipp, Betty, Champion, D.E., Gans, P.B., Van Sistine, D.P., and Snyders, S.R., 2007, Geologic map of the Craters of the Moon 30' $\times 60^{\prime}$ quadrangle, Idaho: U.S. Geological Survey Scientific Investigations Map 2969, scale 1:100,000.

Kuntz, M.A., Skipp, Betty, and Moye, F.J., 1994, Preliminary geologic map of Craters of the Moon $30^{\prime} \times 60^{\prime}$ quadrangle: U.S. Geological Survey Open-File Report 94-659, scale $1: 100,000,77 \mathrm{p}$
Larson, T.A., 1974, Geology of T. 1 N. and T. 2 N., R. 22 E., R. 23 E., and R. 24 E., Blaine and Butte Counties, southcentral Idaho: Milwaukee, University of Wisconsin, M.S. thesis, $127 \mathrm{p}$.

Link, P.K., Cameron, Angela, Autenrieth, K.M.D., and Fanning, C.M., 2010, Tectonostratigraphy of the Wildhorse gneiss complex, Pioneer Mountains: Neoarchean orthogneiss and overlying Mesoproterozoic Lemhi Group overlie Albion Range Proterozoic Quartzite [abs.]: Geological Society of America Abstracts with Programs, v. 42., no. 5, p. 415.

Link, P.K., Durk, K.M., and Fanning, C.M., 2007, SHRIMP $\mathrm{U}-\mathrm{Pb}$ ages for Archean orthogneiss, Mesoproterozoic paragneiss, and Eocene Boulder Creek pluton, Pioneer Mountains, south-central Idaho, part of the 2,600 Ma Grouse Creek Block [abs.]: Geological Society of America Abstracts with Programs, Denver, v. 39, no. 6, p. 613.

Link, P.K., Mahoney, J.B., Bruner, D.J., Batatian, L.D., Wilson, Eric, and Williams, F.J.C., 1995, Stratigraphic setting of sediment-hosted mineral deposits in the eastern part of the Hailey $1^{\circ} \times 2^{\circ}$ quadrangle and part of the Challis $1^{\circ} \times 2^{\circ}$ quadrangle, south-central Idaho, in Worl, R.G., Link, P.K., Winkler, G.R., and Johnson, K.M., eds., Geology and mineral resources of the Hailey $1^{\circ} \times 2^{\circ}$ quadrangle and the western part of the Idaho Falls $1^{\circ} \times 2^{\circ}$ quadrangle, Idaho: U.S. Geological Survey Bulletin 2064-C, p. C1-C33.

Link, P.K., Warren, Ian, Preacher, J.M., and Skipp, Betty, 1996, Stratigraphic analysis and interpretation of the Mississippian Copper Basin Group, McGowan Creek Formation, and White Knob Limestone, south-central Idaho, in Longman, M.W., and Sonnenfeld, M.D., eds., Paleozoic Systems of the Rocky Mountain Region, Rocky Mountain Section: Society for Sedimentary Geology, p. 117-144. Mahoney, J.B., Link, P.K., Burton, B.R., Geslin, J.K., and O’Brien, J.P., 1991, Pennsylvanian and Permian Sun Valley Group, Wood River Basin, south-central Idaho, in Cooper, J.D., and Stevens, C.H., eds., Paleozoic Paleogeography of the Western United States II: Field Trip Guidebook-Pacific Section, Society of Economic Paleontologists and Mineralogists, v. 67, p. 551-579.

Morgan, L.A., and McIntosh, W.C., 2005, Timing and development of the Heise volcanic field, Snake River Plain, Idaho, western USA: Geological Society of America Bulletin, v. 117, no. 3/4, p. 288-306.

Moye, F.J., Hackett, W.R., Blakely, J.D., and Snider, L.G., 1988, Regional geologic setting and volcanic stratigraphy of the Challis volcanic field, central Idaho, in Link, P.K., and Hackett, W.R., eds., Guidebook to the geology of central and southern Idaho: Idaho Geological Survey Bulletin 27, p. 87-97. 
Moye, F.J., Hackett, W.R., Snider, L.G., Snee, L.W., and Mertzman, S.A., Jr., 1995, The southeastern Challis volcanic field, central Idaho, part 1, stratigraphy, chronology, and petrology, appendix 5F, in Snider, L.G., ed., Stratigraphic framework, geochemistry, geochronology, and eruptive styles of Eocene volcanic rocks in the White Knob Mountains area, southeastern Challis Volcanic Field, central Idaho: Pocatello, Idaho State University, unpub. M.S. thesis, p. 202-212.

Moye, F.J., Leeman, W.P., Hackett, W.R., Honjo, N., Bonnichsen, Bill, and Clarke, C., 1988, Cenozoic volcanic stratigraphy of the Lake Hills, Blaine County, Idaho [abs.]: Geological Society of America Abstracts with Programs, v. 20, no. 6, p. 434.

Nelson, W.H., and Ross, C.P., 1969, Geologic map of the Mackay quadrangle, south-central Idaho: U.S. Geological Survey Miscellaneous Geological Investigations Map I-580, scale 1:125,000.

Nelson, W.H., and Ross, C.P., 1969, Geology of the Mackay 30-minute quadrangle, Idaho: U.S. Geological Survey Open-File Report 70-242, $161 \mathrm{p}$.

Nilsen, T.H., 1977, Paleogeography of Mississippian turbidites in south-central Idaho, in Stewart, J.H., Stevens, C.H., and Fritsche, A.E., eds., Paleozoic paleogeography of the Western United States: Pacific Coast Paleogeography Symposium I: Society of Economic Paleontologists and Mineralogists, Pacific section, p. 275-299.

Otto, B.R., and Zieg, G.A., 2003, Geology of an Ordovician stratiform base-metal deposit in the Long Canyon area, Blaine County, Idaho: U.S. Geological Survey Bulletin 2064-KK, 11 p. (available online).

Paull, R.A., 1974, Upper Cretaceous (?) to lower Eocene post-orogenic conglomerate, south-central Idaho [abs.]: Geological Society of America Abstracts with Programs, v. 6, no. 5, p. 466.

Paull, R.A., and Gruber, D.P., 1977, Little Copper Formation: new name for lowest formation of Mississippian Copper Basin Group, Pioneer Mountains, south-central Idaho: American Association of Petroleum Geologists Bulletin, v. 61 , no. 2, p. 256-262.

Paull, R.A., Wolbrink, M.A., Volkmann, R.G., and Grover, R.L., 1972, Stratigraphy of Copper Basin Group, Pioneer Mountains, south-central Idaho: American Association of Petroleum Geologists Bulletin, v. 56, no. 8, p. 1370-1401.

Pierce, K.L., and Morgan, L.A., 1992, The track of the Yellowstone hot spot: Volcanism, faulting, and uplift, in Link, P.K., Kuntz, M.A., and Platt, L.B., eds., Regional geology of eastern Idaho and western Wyoming: Geological Society of America Memoir 179, p. 1-53.
Rodgers, D.W., Link, P.K., and Huerta, A.D., 1995, Structural framework of mineral deposits hosted by Paleozoic rocks in the northeastern part of the Hailey $1^{\circ} \times 2^{\circ}$ quadrangle, south-central Idaho, in Worl, R.G., Link, P.K., Winkler, G.R., and Johnson, K.M., eds., Geology and mineral resources of the Hailey $1^{\circ} \times 2^{\circ}$ quadrangle and the western part of the Idaho Falls $1^{\circ} \times 2^{\circ}$ quadrangle, Idaho: U.S. Geological Survey Bulletin 2064-B, p. B1-B18.

Sandberg, C.A., Hall, W.E., Batchelder, J.N., and Axelsen, Claus, 1975, Stratigraphy, conodont dating, and paleotectonic interpretation of the type Milligen Formation (Devonian), Wood River area, Idaho: U.S. Geological Survey Journal of Research, v. 3, no. 6, p. 707-720.

Sandberg, C.A., Poole, F.G., and Johnson, J.G., 1988, Upper Devonian of Western United States, in McMillan, N.J., Embry, A.F., and Glass, D.J., eds., Devonian of the World: Calgary, Canadian Society of Petroleum Geologists Memoir 14, v. 1, p. 183-220.

Scott, W.E., 1982, Surficial geologic map of the eastern Snake River Plain and adjacent areas, $111^{\circ}$ to $115^{\circ} \mathrm{W}$., Idaho and Wyoming: U.S. Geological Survey Miscellaneous Investigations Series Map I-1372, scale 1:250,000.

Scott, W.E., Pierce, K.L., and Hait, M.H., Jr., 1985, Quaternary tectonic setting of the 1983 Borah Peak earthquake, central Idaho: Bulletin of the Seismological Society of America, v. 75 , no. 4, p. 1053-1066.

Sidle, W.C., 1979, Geology of north Craters of the Moon National Monument, Idaho: Portland State University, Oregon, M.S. thesis, $65 \mathrm{p}$.

Skipp, Betty, 1989, Geologic map of Mackay 4 (Grouse) NW quadrangle, Butte and Custer Counties, Idaho: U.S. Geological Survey Open-File Report 89-142, scale 1:24,000.

Skipp, Betty, and Bollmann, D.D., 1992, Geologic map of the Blizzard Mountain North quadrangle, Blaine and Butte Counties, Idaho: U.S. Geological Survey Open-File Report 92-280, scale 1:24,000.

Skipp, Betty, and Hall, W.E., 1975, Structure and Paleozoic stratigraphy of a complex of thrust plates in the Fish Creek Reservoir area, south-central Idaho: U.S. Geological Survey Journal of Research, v. 3, no. 6, p. 671-689.

Skipp, Betty, Kuntz, M.A., and Morgan, L.A., 1990, Geologic map of Mackay 4 (Grouse) SE quadrangle, Butte County, Idaho: U.S. Geological Survey Open-File Report 89-431, scale $1: 24,000$.

Skipp, Betty, and Sandberg, C.A., 1975, Silurian and Devonian miogeosynclinal and transitional rocks of the Fish Creek Reservoir window, central Idaho: U.S. Geological Survey Journal of Research, v. 3, no. 6, p. 691-706.

Skipp, Betty, Snider, L.G., Janecke, S.U., and Kuntz, M.A., 2009, Geologic map of the Arco 30' $\times 60^{\prime}$ quadrangle, south-central Idaho: Idaho Geological Survey Map 47, GM-47, scale 1:100,000, 42 p. 
Snider, L.G., 1995, Stratigraphic framework, geochemistry, geochronology, and eruptive styles of Eocene volcanic rocks in the White Knob Mountains area southeastern Challis Volcanic Field, central Idaho: Pocatello, Idaho State University, M.S. thesis, 212 p., scales 1:100,000 and 1:24,000.

Snider, L.G., and Moye, F.J., 1989, Regional stratigraphy, physical volcanology, and geochemistry of the southeastern Challis volcanic field, in Winkler, G.R., Soulliere, S.J., Worl, R.G., and Johnson, K.M., eds., Geology and mineral deposits of the Hailey and western Idaho Falls $1^{\circ} \times 2^{\circ}$ quadrangles, Idaho: U.S. Geological Survey OpenFile Report 89-639, p. 122-127.

Wilson, Eric, Preacher, J.M., and Link, P.K., 1994, New constraints on the nature of the Early Mississippian Antler sedimentary basin in Idaho, in Embry, A.F., Beauchamp, B., and Glass, D.J., eds., Pangea: Global Environments and Resources: Canadian Society of Petroleum Geologists Memoir 17, p. 155-174.
Wohletz, K.H., and Sheridan, M.F., 1979, A model of pyroclastic surge, in Chapin, C.C., and Elston, W.E., eds., Ash-Flow Tuffs: Geological Society of America Special Paper 180, p. 177-194.

Worl, R.G., and Johnson, K.M., 1995, Geology and mineral deposits of the Hailey $1^{\circ} \times 2^{\circ}$ quadrangle and the western part of the Idaho Falls $1^{\circ} \times 2^{\circ}$ quadrangle, south-central Idaho-An overview, in Worl, R.G., Link, P.K., Winkler, G.R., and Johnson, K.M., eds., Geology and mineral resources of the Hailey $1^{\circ} \times 2^{\circ}$ quadrangle and the western part of the Idaho Falls $1^{\circ} \times 2^{\circ}$ quadrangle, Idaho: U.S. Geological Survey Bulletin 2064-A, p. A1-A21, plate 1 , scale 1:250,000.

Worl, R.G., Kiilsgaard, T.H., Bennett, E.H., Link, P.K., Lewis, R.S., Mitchell, V.E., Johnson, K.M., and Snyder, L.D., 1991, Geologic map of the Hailey $1^{\circ} \times 2^{\circ}$ quadrangle, Idaho: U.S. Geological Survey Open-File Report 91-340, scale 1:250,000.
Publishing support provided by:

Denver Publishing Service Center, Denver, Colorado

For more information concerning this publication, contact:

Center Director, USGS Central Mineral and Environmental Resources Science Center

Box 25046, Mail Stop 973

Denver, CO 80225

(303) 236-1562

Or visit the Central Mineral and Environmental Resources Science Center Web site at: http://minerals.cr.usgs.gov/

This publication is available online at: http://pubs.usgs.gov/sim/3191/ 
몽

응

ํㅗㅇ

웅

完

꽁

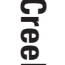

商

愚

을.

구

을

흑 